\title{
Explain and evaluate the congruence between the brand personality and word of mouth advertising
}

\author{
Mohammad Rezaei ${ }^{1, *}$, Mohammad Reza HAMidizadeH ${ }^{2}$, Fahime Foroughi ${ }^{3}$ \\ ${ }^{1}$ Department of management, shahid beheshti University, Tehran, Iran email address: \\ mohammadrezaei23@yahoo.com , telephone number:00989171240830 \\ ${ }^{2}$ Faculty of Management, shahid beheshti University, Tehran, Iran \\ email address: M-Hamidizadeh@sbu.ac.ir , contact telephone number:00989123907992 \\ ${ }^{3}$ Department of management, Tehran Science and Research Branch, Islamic Azad \\ University, Tehran, Iran email address: fahimeforoughi@yahoo.com , contact telephone \\ number:00989132236106 \\ *corresponding author: mohammadrezaei23@yahoo.com
}

\section{Abstract}

Today, marketing researchers have considered creating a good congruency between clients and Brands personality. Because, it has two of the most important consequences; one, creating a long term relationship and two, word of mouth. Hence, this research has been to explain the relationship of the brand personality congruency and word of mouth with mediating customer-brand relationship in the banking industry. The study sample is including all students at the Shahid Beheshti University. In the sampling, the sample was calculated using Cochran formula, minimum requirement of 385 samples. Then, randomly and easy, 412 questionnaires were collected and; their data was used. In order to analyze Questionnaire data and test hypotheses was performed description test, means comparison and structural equation modeling using Smart-PLS software. The results show that personality congruency has positive and significance effect on customer-brand relationship dimensions (SelfConnection, Partner Quality and Affective Commitment); and relationships have been confirmed. Also, relationship between customer-brand relationship dimensions and word of mouth have been confirmed; and they have positive and significance effect. According to results of total effect, the largest total effect for word of mouth, it belongs to personality congruency (0.705); and this effect is only indirect. After personality congruency, partner quality has more effective on word of mouth (0.367).

Keywords: Personality Congruency (PC), Customer-Brand Relationship Dimensions, Word Of Mouth.

\section{Introduction}

Brand is the name, sign, symbol, or a combination of these factors that distinguishes the goods or services of one seller or a group of sellers from other competitors (Cutler, 1997). The American Marketing Association defines brand; the brand is name, phrase, symbol, 
design or a combination of these factors that indicates the nature and the existence of a company, product or service (Dehdashti Shahrokh et al. 2012). Brand is a part of operational and emotional characteristics of the product / service / business that is reflected by the customer and is a helpful tool in decision-making for customers and creating value for the business. Hence, today, the brand is considered as one of the most important marketing issues. Another concept that arises in connection with the brand is the brand identity. Brand identity is a set of unique communications of a brand in the form of slogan, promises to the customer and cause to create a new identity and improving its former identity. In general, consumers tend to use brands that with their personal characteristics (self-concept) are compatible (Belk, 1988). Thus it can be stated explicitly that businesses can affect decision process and purchase of potential customers by improving and strengthening the congruency between the consumer and the brand. Ardndt (1967) is one of the first researchers that refer to the concept of words of mouth advertising (Seyed Javadin et al., 2011; litvin et al., 2007). He introduces word of mouth advertising as face to face communication between people about the product or company and believes that this relationship not has a commercial nature or is virtually independent of commercial activities of company. Congruency of brand personality and word of mouth advertising is very important in the banking industry and the need to investigate the factors affecting it, more than ever is felt. The importance of recognizing personality characteristics of customer in the banking industry as well as the role that this consistency can have with the brand personality characteristics to differentiate in a competitive market environment and in addition, the relationship between this congruency with index of publish in word of mouth advertising for banks are factors that add to the necessity of doing this study. Hence, the main purpose of this research is to identify the congruency between personality and dimensions of the consumer-brand relationship, relationship of dimensions, the relationship between the consumer-brand on word of mouth advertising and explaining the level of customer satisfaction based on personality congruency and word of mouth advertising. Finally, this research seeks to answer the fundamental question: Do the dimensions of consumer-brand relationship affect the congruency of consumer-brand personality? And at a higher level, does the improvement of the consumerbrand relationship cause word of mouth advertising from the customers?

\section{Background and theoretical foundations Brand personality}

Customers often by giving personality to brands value them for their human side, and marketers often with the help of positioning, create or reinforce this perception (Azizi et al., 2012). Brand personality is one of the main components of brand identity (Azizi et al., 2012). Also, Aaker (1997) introduce brand personality as one of the main aspects of brand identity and as the closest concept that affects decision-making process of purchase. Brand identity has a multi-dimensional structure in which the brand personality is seen as one of the main constituents of brand identity (Jones et al., 2009). Hamidizadeh et al (2012) in a study announced that today brand personality is one of the most attractive concepts in marketing; also, the literature shows that many researchers have investigated this concept. But by studying the literature can consider "Martineau" (1957) as the first person that has proposed the concept of identifier personality. The most important and influential researcher is Aaker (1997) that plays the key role in the definition and introduction of measures, as far as researchers consider his defining about identifier personality as the most comprehensive and most prestigious definition: "a set of human characteristics associated with identifier "(Hamidizadeh et al., 2012). Of course, there are other definitions; Azoulay and Kapferer (2003) define identifier personality: "a set of features of human personality that is applicable 
Bulletin de la Société Royale des Sciences de Liège, Vol. 85, 2016, p. 1514 - 1528

and relevant to identifier ". Or Ferrandi and Walt-Florence (2002): "All personality traits that are used for describing person and associated with the identifier". 
Table 1: Dimensions of personality (Big Five Factor)

\begin{tabular}{|c|c|}
\hline $\begin{array}{c}\text { Personality } \\
\text { dimensions }\end{array}$ & The ways of showing traits \\
\hline Extroversion & Willing to participate, speaking in front of others, daring and fearless \\
\hline $\begin{array}{c}\text { Lack of behavioral } \\
\text { instability }\end{array}$ & irritability, fast and unreasonable change of mood, sensitivity and \\
irritability
\end{tabular}

Source: Hawkins et al. (2006, p. 279)

"Aaker" by inspiring Big Five Factor Model has designed a model for measuring brand personality and its dimensions are honesty, excitement, competence, skill and perfection and violence (Azizi et al., 2012). The five dimensions with 42 items are consistent with North American culture (Hamidizadeh et al., 2012)

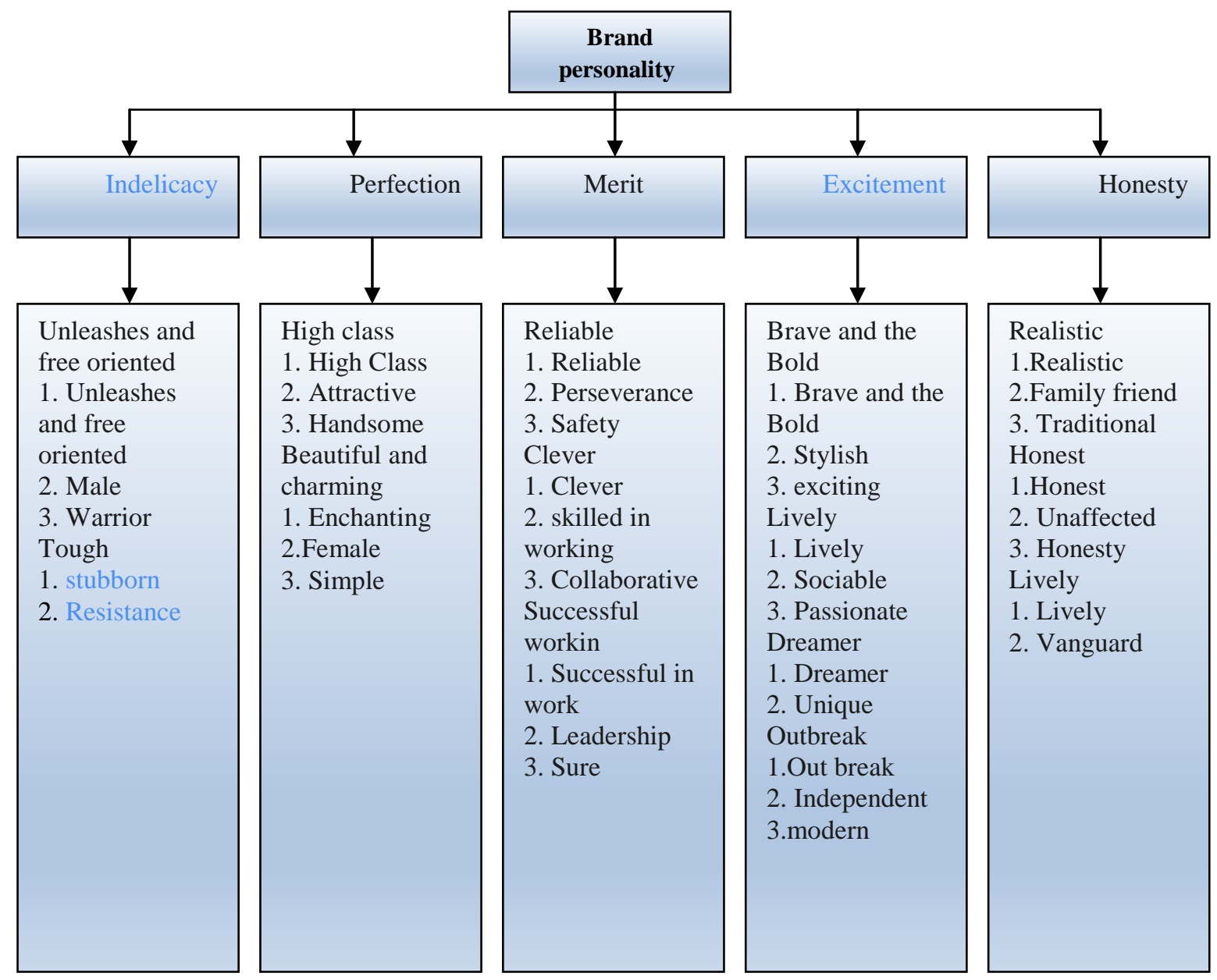

Figure 1: Aker model (1991) 


\section{Congruency of brand personality}

Congruency is the existing of fitness between personality and behavior of person (shopping), in a particular situation (Sherman et al., 2012). Most brands have been deprived of the attention of consumers because their personality not satisfied feelings of consumers. Thus, consumers avoid of products / brands that not have compatibility and congruency with their image. (Shane, 2012). Hosany and Martin (2011) state that image congruency that person feel with the considered brand plays a major role in influencing consumer behavior and have expressed, for example, the congruency affects the effectiveness of the advertising and causes to facilitate in the creation of positive attitudes toward products and brands, and can effect choosing consumers, attitudes, perceived quality, preferences towards brand, and brand loyalty.

\section{Word of mouth advertising (publication index)}

Ardndt (1967) is one of the first researchers who has refered to the concept of word of mouth advertising (Seyed Javadiyan, Barabari and Allahyari, 2011; litwin et al., 2007). He introduces word of mouth advertising as face to face communication about the products or companies between people and He believes that this relationship not has a commercial nature or is independent of commercial activity.

Word of mouth advertising especially in the service sector has great importance because services are intangible and is based on the expertise and credibility (Seyed Javadiyan et al., 2011). In this context, Ng et al (2011) suggest that in service sectors, purchase is done based on the recommendations of others basically, because according to the nature of the services, people usually consult with people who experienced this type of service and get help of their recommendations (Gremler et al., 2001).

According to studies carried out in Iran, no studies have directly investigated the impact of congruency of personality on the dimensions of consumer-brand relationship as well as its impact on encouraging customers to mouth advertising. But there are a number of articles that as case study are investigated each of the variables in this study. In general, due to the introduction of some new variables such as personality congruence and consumer-brand relationship in Iran, there are a few articles in these cases. But during studies that have been done in foreign papers, there are a number of articles that have investigated the relationship between some variables, in the following we will investigate them.

\section{Congruency between personality and customer-business relationship}

Congruency and compatibility between the customer and the brand personality develop brand and customer relationship (Shane, 2012). During the study that Aker and colleagues (2004) conducted, they investigated the effect of two dimensions of brand personality on consumerbrand relationships, and concluded that "relationship between the consumer-brand" is always stronger in intimate brands and since features such as "family orientation", "good-natured" and "friendship" has specified, the character of intimacy is positively associated with the "consumer-brand relationships". On the contrary, they concluded that "consumer-brand relationships" with exciting brands is not strong, since the characteristics of youth, pride and independence that have specified that character of the exciting is fascinating and interesting, but with "the relationship between the consumer-brand" is negatively correlated. Park and Lee (2005) in their research investigated the impact of congruency between brand personality and self-image with the mediation of the role of satisfaction and the consumerbrand relationship on the loyalty. Their results show that congruency between the brand 
personality and self-image, not only increases consumer satisfaction but also improves the relationship between consumer and brand. (Figure 3)

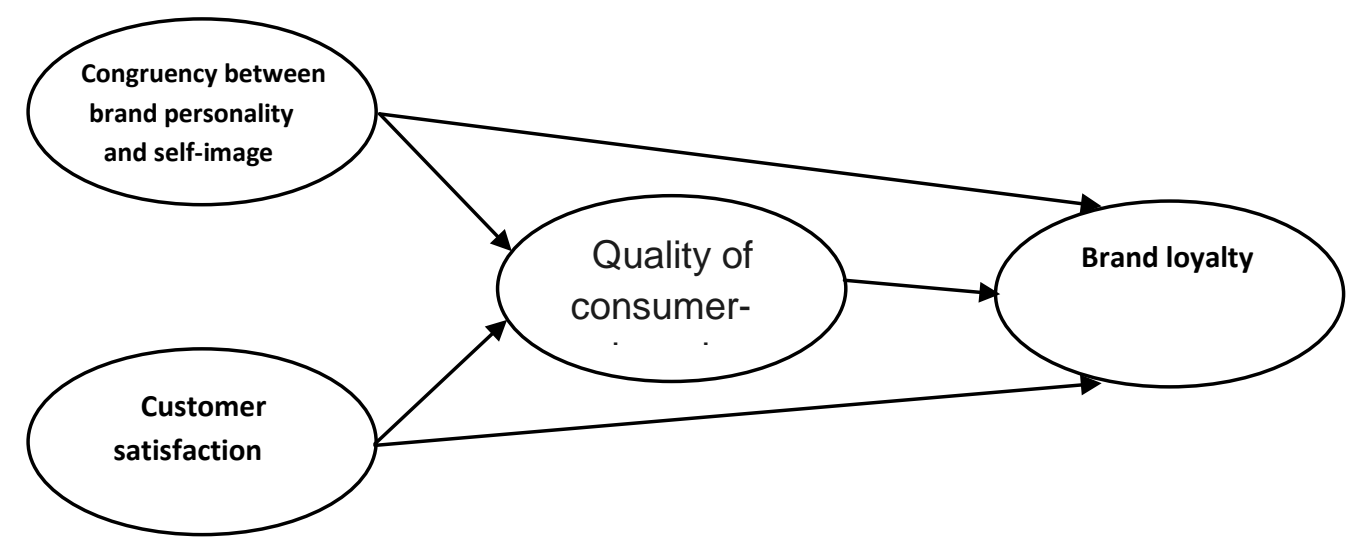

Figure 2: The impact of personality congruency on consumer-brand relationship

To measure personality congruency, first using the model of Jones et al (2009) each of the characters related to the consumer and the brand are assessed and then using the model of Sergi and Denc (1982), congruency will be assessed.

$$
\mathrm{D}=\frac{\sum_{i=1}^{n}|(\mathrm{BP}-\mathrm{SP})|}{\mathrm{n}}
$$

Variable relationship, customer- business relationship and word of mouth advertising Consumer-brand relationship and loyalty has been approved during studies that a number of researchers have conducted and have stated that consequences of strong relationship with customer are; word of mouth advertising (Crosby et al. 1990); reducing the costs of tradings; increasing the volume of purchases; to stay (Morgan and Hunt, 1994) and collaboration (Pruitt, 1981). To assess consumer-brand relationship, Aaker indicators (2004) are used. They have considered consumer-brand relationship four dimensions, that they are four dimensions of "intimacy, effective commitment, self-communication, and partners' quality. In scales of "word of mouth advertising", the study of Maxham and Netemeyer (2004) will be used. Figure (4) shows the conceptual model.

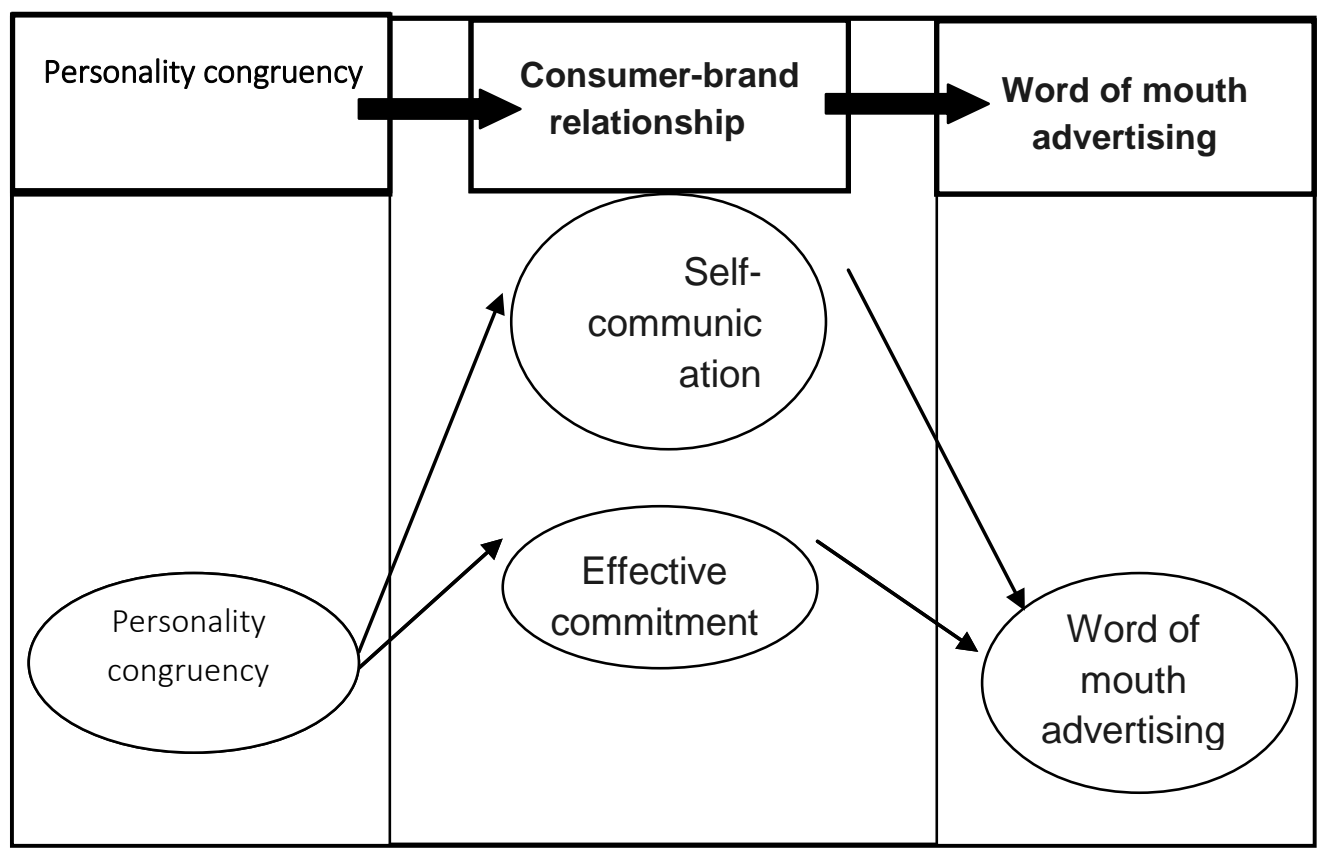


With regard to the history and theoretical foundations of research as well as the conceptual model of above, major hypotheses that this study is conducted to investigate them are:

First hypothesis: Self- communication has a positive relationship with personality congruency.

Second: Word of mouth advertising has a positive relationship with effective commitment. hypothesis:

Third hypothesis: Partners' quality has a positive relationship with personality congruency. Fourth hypothesis: Effective commitment has a positive relationship with personality congruency.

Fifth hypothesis: Word of mouth advertising has a positive relationship with partners' quality.

Sixth hypothesis: Word of mouth advertising has a positive relationship with selfcommunication.

\section{Research Methodology}

\subsection{Methodology}

Type of present research in terms of the purpose and nature of the issue studied is applied research, in terms of collected data is a survey research and in terms of the method of research is a descriptive research. A questionnaire was used to collect research data.

\subsection{Measures (questionnaire)}

To survey in the environment, a questionnaire based on five-option scale was used. The research consists of three main variables "personality congruency" "consumer-brand relationship" and "word of mouth advertising", which were measured by a set of variables. In this research, personality congruency was divided into two dimensions of "customer personality" and "brand personality". In order to measure variables of "customer personality", 13 items were used, to "brand personality", 12 items, to "consumer-brand relationship", 21 items and to "word of mouth advertising", 3 items were used. Source of adapting items of questionnaire and general information is summarized in table 2.

Table 2: Variables and their dimensions in the research model and combining questions of questionnaire

\begin{tabular}{|c|c|c|c|c|}
\hline Variables & Major dimensions & $\begin{array}{c}\text { The number of } \\
\text { questions of } \\
\text { questionnaire }\end{array}$ & $\begin{array}{c}\text { Cronbach's } \\
\text { alpha } \\
\text { coefficient }\end{array}$ & Derived from... \\
\hline \multirow{2}{*}{$\begin{array}{c}\text { consumer- } \\
\text { brand } \\
\text { relationship }\end{array}$} & $\begin{array}{c}\text { Intimacy } \\
\text { communication }\end{array}$ & 5 & 0.906 & $\begin{array}{c}\text { Aaker, Fournier } \\
\text { and Brussels } \\
\text { (2004) }\end{array}$ \\
\cline { 2 - 3 } & $\begin{array}{c}\text { Effective } \\
\text { commitment }\end{array}$ & 5 & & \\
\cline { 2 - 3 } & Partners' quality & 6 & \multirow{2}{*}{0.825} & $\begin{array}{c}\text { Magez Ham\& } \\
\text { Natmayer(2002) }\end{array}$ \\
\hline \multirow{2}{*}{$\begin{array}{c}\text { word of mouth advertising } \\
\text { bersonality }\end{array}$} & Accountability & 3 & \multirow{2}{*}{0.789} & $\begin{array}{c}\text { Jones, Peter and } \\
\text { the Wolf (2009) }\end{array}$ \\
\cline { 2 - 3 } & Mobility & 3 & & \\
\cline { 2 - 3 } & Emotional & 2 & & \\
\cline { 2 - 3 } & Audacity & 2 & & \\
\cline { 2 - 3 } & Simplicity & 2 & & \\
\hline
\end{tabular}




\begin{tabular}{|c|c|c|c|c|}
\hline \multirow{3}{*}{$\begin{array}{c}\text { customer } \\
\text { personality }\end{array}$} & Accountability & 3 & \multirow{2}{*}{0.716} & Jones, Vickers \\
\cline { 2 - 3 } & Mobility & 3 & & Wolf (2009) \\
\cline { 2 - 3 } & Emotional & 3 & \\
\cline { 2 - 3 } & Audacity & 2 & \\
\cline { 2 - 3 } & Simplicity & 2 & & \\
\hline
\end{tabular}

\section{3 data analysis method}

For the analysis of data and test of hypotheses, structural equation modeling (SEM), and Friedman's correlation coefficient is used. On the other hand, Cronbach's alpha coefficient is used to assess reliability. Finally, in order to analyze the data, SPSS and SmartPLS software package is used.

\subsection{Population and sample}

This study is done to explain and evaluate the congruency between brand personality and publication index in the banking industry. The study population included all students of Shahid Beheshti University. The researcher has considered a sample of 385 samples that to determine it, Cochran formula is used:

\section{3 validity and reliability}

In this study, by collecting 30 prototypes, the reliability of questionnaire was investigated. After reviewing the data using software SPSS, reliability coefficient was obtained 0.932. Reliability coefficient of all variables is more than 0.7 so the research has an appropriate reliability. In order to determine the validity or reliability of the content, the questionnaire for this study was reviewed and approved by professors and academic elites in several stages.

\section{Findings}

\subsection{Descriptive findings}

In order to better understanding of the nature of the sample before analysis, the data is required to be described. The results of the demographic data are in Table 3.

Table 3: Demographic variables

\begin{tabular}{|c|c|c|c|c|c|c|c|}
\hline Variable & Range & Number & Percentage & Variable & Range & Number & Percentage \\
\hline \multirow[t]{2}{*}{ Gender } & Male & 240 & 58.3 & \multirow[t]{3}{*}{ Education } & $\begin{array}{l}\text { Bachelor } \\
\text { student }\end{array}$ & 241 & 58.5 \\
\hline & Female & 172 & 41.7 & & $\begin{array}{l}\text { Master } \\
\text { student }\end{array}$ & 112 & 27.2 \\
\hline \multirow[t]{4}{*}{ Age } & $\begin{array}{l}\text { Less than } \\
20 \text { years }\end{array}$ & 107 & 26 & & $\begin{array}{c}\text { Ph.D } \\
\text { student }\end{array}$ & 59 & 14.4 \\
\hline & $\begin{array}{l}20-23 \\
\text { years }\end{array}$ & 160 & 38.8 & \multirow[t]{3}{*}{$\begin{array}{c}\text { Marital } \\
\text { status }\end{array}$} & Single & 355 & 86.2 \\
\hline & $\begin{array}{l}24-26 \\
\text { years }\end{array}$ & 111 & 26.9 & & Married & 57 & 13.8 \\
\hline & $\begin{array}{c}\text { More than } \\
26 \text { years }\end{array}$ & 34 & 8.3 & & & & \\
\hline
\end{tabular}




\subsection{Test of hypotheses}

First to investigate the relationship between variables of each hypotheses, Pearson correlation coefficient is used. The results of Pearson correlation coefficients are shown in Table 4. As you can see in this table, the relationship of personality congruency with variables of selfcommunication and partners' quality at confidence level of $99 \%$ and with variables of intimacy and effective commitment at confidence level of 95 percent is significant. The relationship of word of mouth advertising and variables of intimacy, self- communication, effective commitment and partners' quality is significant at a confidence level of 99\%. Given the significance of the relationship between variables of hypotheses, the research hypotheses will be tested.

Table 4: Results of correlation test

\begin{tabular}{|c|c|c|c|c|c|c|c|c|}
\hline Variables & Mean & $\begin{array}{c}\text { Standard } \\
\text { deviation }\end{array}$ & $\begin{array}{c}\text { Personality } \\
\text { congruency }\end{array}$ & Intimacy & $\begin{array}{c}\text { Self- } \\
\text { communication }\end{array}$ & $\begin{array}{c}\text { Effective } \\
\text { commitment }\end{array}$ & $\begin{array}{c}\text { Partners' } \\
\text { quality }\end{array}$ & $\begin{array}{c}\text { Word of } \\
\text { mouth } \\
\text { advertising }\end{array}$ \\
\hline $\begin{array}{c}\text { Personality } \\
\text { congruency }\end{array}$ & 3.66 & 0.68 & 1 & & & & & \\
\hline Intimacy & 3.04 & 0.87 & ${ }^{*} 0.297$ & 1 & & & & \\
\hline $\begin{array}{c}\text { Self- } \\
\text { communication }\end{array}$ & 3.55 & 0.63 & ${ }^{* *} 0.3$ & ${ }^{* *} 0.765$ & 1 & & & \\
\hline $\begin{array}{c}\text { Effective } \\
\text { commitment }\end{array}$ & 3.65 & 0.69 & ${ }^{*} 0.175$ & $* * 0.695$ & ${ }^{* *} 0.786$ & 1 & & \\
\hline $\begin{array}{c}\text { Partners' } \\
\text { quality }\end{array}$ & 3.75 & 0.62 & ${ }^{* *} 0.66$ & $* * 0.735$ & ${ }^{* *} 0.7$ & ${ }^{* *} 0.55$ & 1 & \\
\hline $\begin{array}{c}\text { Word of mouth } \\
\text { advertising }\end{array}$ & 3.55 & 0.78 & ${ }^{* *} 0.329$ & $* * 0.784$ & $* * 0.822$ & ${ }^{* *} 0.712$ & $* * 0.796$ & 1 \\
\hline
\end{tabular}

** Significance at a confidence level of $99 \%$. * Significance is at 95 percent confidence level.

The results of research hypotheses test is shown in Table 5. As you can see in this table, according to the statistic t, first, second, third, fourth, fifth and eighth hypotheses in the 99\% confidence level and sixth and seventh hypotheses at confidence level of 95\% have been approved. Accordingly, it can be concluded that personality congruency at confidence level of 99 percent affect intimacy, self-communication, effectiveness commitment and partners' quality; on the other hand, variables of intimacy and partners' quality at 99 percent and selfcommunication and effective commitment at confidence level of 95 percent affect the word of mouth advertising.

According to coefficients of path can be concluded that the impact of personality congruency on intimacy, self-communication, effective commitment, partners' quality and impact of intimacy, self-communicant, effective commitment, partners' quality on word of mouth advertising in linear type is positive and direct, that is, with the increase of independent variables in one percent, the dependent variable increases in the coefficient of path and vice versa. For example, by improving the variable of personality congruency in one percent, 99 percent probably the intimacy improves at a rate of $0.12 \%$. Path coefficient related to the other hypotheses can also be interpreted in the same way. 
Coefficient of determination (r2) related to the impact of personality congruency on the variables of intimacy, self-communication, effective commitment, and partners' quality, is respectively, $0.480,0.745,0.500,0.391$. These values indicate that the factor of personality congruency has abled to predict, $0.480,0.745,0.500,0.391$ per cent of the changings of the variables of intimacy, self-communication, effective commitment, and partners' quality. While respectively $0.520,0.255,0.500$, and 0.609 percent is related to prediction error and can include other variables that influence intimacy, self-communication, effective commitment, partners' quality.

Coefficient of determination related to the impact of all components of intimacy, selfcommunication, effective commitment and partners' quality on word of mouth advertising is 0.839. This value indicates that the components of intimacy, self-communication, effective commitment and partners' quality could predict 0.839 percent of the changes of word of mouth advertising and the rest 0.161 percent is related to prediction error and can include other variables affected word of mouth advertising.

Table 5: test of research hypotheses

\begin{tabular}{|c|c|c|c|c|}
\hline Research hypotheses & $\begin{array}{c}\text { Path } \\
\text { coefficient }\end{array}$ & t static & Result & $\begin{array}{l}\text { Coefficient of } \\
\text { determination } \\
\left(\mathrm{r}^{2}\right)\end{array}$ \\
\hline $\begin{array}{l}\text { 1.the impact of personality congruency on } \\
\text { intimacy }\end{array}$ & 0.69 & $13.69 * *$ & Confirmed & 0.480 \\
\hline $\begin{array}{l}\text { 2. the impact of personality congruency on } \\
\text { self-communication }\end{array}$ & 0.86 & $33.45 * *$ & Confirmed & 0.745 \\
\hline $\begin{array}{l}\text { 3. the impact of personality congruency on } \\
\text { effective commitment }\end{array}$ & 0.70 & $* * 15.05$ & Confirmed & 0.500 \\
\hline $\begin{array}{l}\text { 4. the impact of personality congruency on } \\
\text { partners' quality }\end{array}$ & 0.62 & $* * 11.08$ & Confirmed & 0.391 \\
\hline $\begin{array}{l}\text { 5. the impact of intimacy on word of mouth } \\
\text { advertising }\end{array}$ & 0.31 & $3.84^{* *}$ & Confirmed & \multirow[t]{4}{*}{0.839} \\
\hline $\begin{array}{l}\text { 6. the impact of self-communication on word } \\
\text { of mouth advertising }\end{array}$ & 0.19 & $2.04 *$ & Confirmed & \\
\hline $\begin{array}{l}\text { 7. the impact of effective commitment on } \\
\text { word of mouth advertising }\end{array}$ & 0.15 & $2.01 *$ & Confirmed & \\
\hline $\begin{array}{l}\text { 8. the impact of partners' quality on word of } \\
\text { mouth advertising }\end{array}$ & 0.26 & $* * 4.89$ & Confirmed & \\
\hline
\end{tabular}

** Significance at a confidence level of $99 \%$. * Significance is at 95 percent confidence level.

The amounts of factor loadings and coefficients of path of final test version is shown in figure (5). 


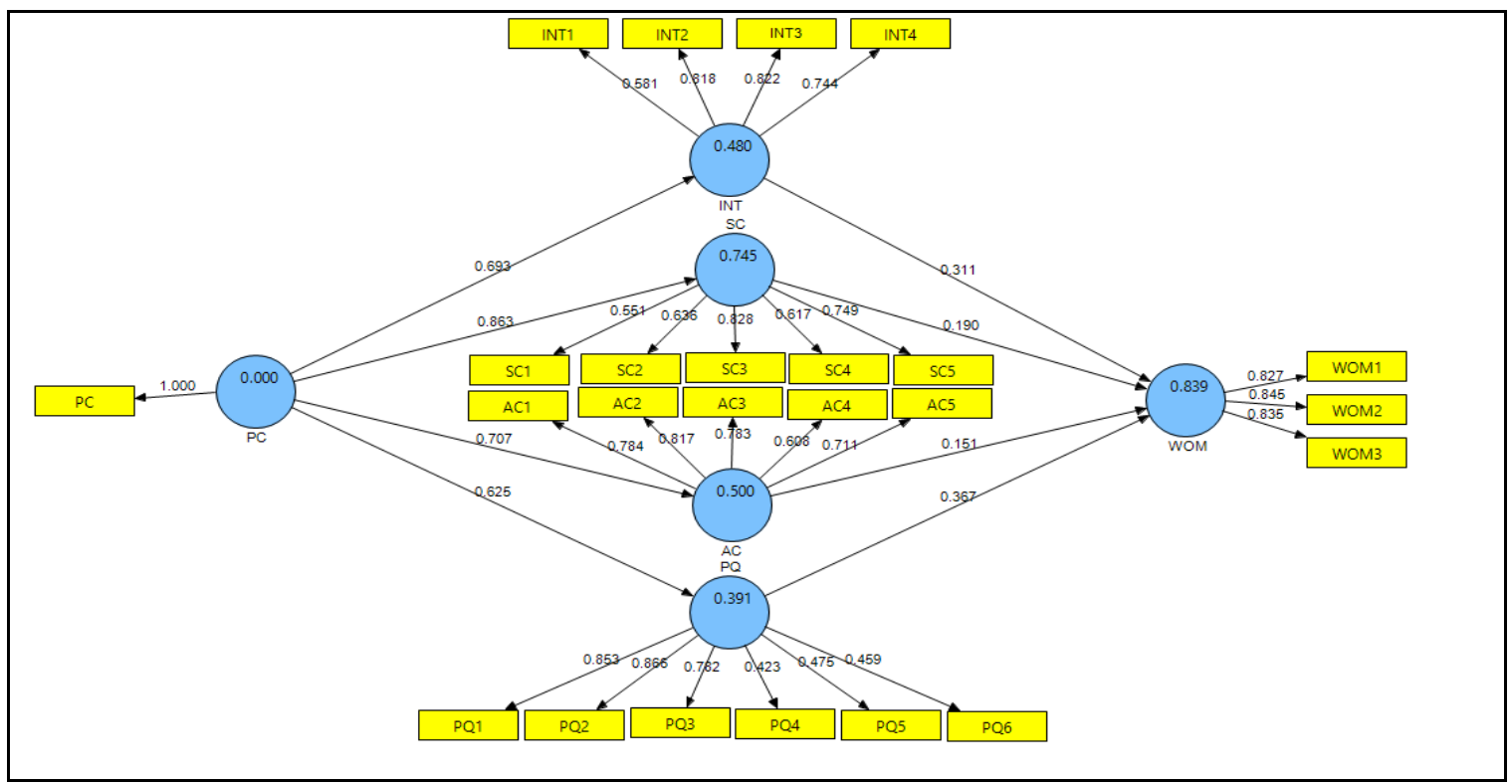

Figure 5: The factor loadings and path coefficients of final tested model

\subsection{Friedman test}

By utilizing Friedman test, the importance of each of the latent variables in the model is provided in the population (Shahid Beheshti University) (Table 6). Significant index of Friedman test with the amount of standard less than five percent (Sig $=0.000$ ) for this test rejects the equality of mean of the variables and shows the significance of difference of mean. Results of test and mean show that personality congruency has the most rates and intimacy has the lowest rate, Chi-square for this test is 446.098 .

Table 6: Test results of Friedman

\begin{tabular}{|c|c|}
\hline Variables & Ranking \\
\hline Personality congruency & 3.9 \\
\hline Intimacy & 1.87 \\
\hline Self- communication & 3.45 \\
\hline Effective commitment & 3.87 \\
\hline Partners' quality & 4.34 \\
\hline Word of mouth advertising & 3.57 \\
\hline Chi square & 446.098 \\
\hline Significant level & 0.000 \\
\hline
\end{tabular}

\section{Discussion and Conclusion}

Brands as a valuable and long-term asset of company must be managed. One of the new subject that is considered in the field of brand and branding in recent years is the attribution of human characteristics to brands that is mentioned as a "brand personality", congruency of brand personality and customer characteristics is another important issue that has been considered in this study. Given the importance of the banking sector and transactions through 
this in the economy and people's living conditions, this study was conducted in the banking industry. The test of model and hypotheses of research showed that personality congruency helps to intimacy means creating a good relationship and intimate between the customer and the bank. Emphasizing the banking sector and CEO on the need to consider the issue of personality congruency can lead to intimacy between the customer and the bank. This intimacy in turn can create the field of brand loyalty and zeal. On the other hand, intimacy strengthens customers' word of mouth advertising; exist a sense of intimacy between the customer and the bank will cause that customer does positive advertising for bank to others and encourages them to use the bank financial services. In other area, personality congruency improves self- communication, that is, create a proper fit between the customer personality and the bank will cause the customer feel closer to the bank. This feeling can affect customer satisfaction and create the field of loyalty. From another dimension, self-communication will strengthen word of mouth advertising; when brand (banks) is able to establish communication with the customer and identify and resolve their internal requirements, will cause the customer does positive advertising to the bank to others and encourage them to use the bank financial services. The results also showed that personality congruency strengthens effective commitment of customers; the creation of a proper fit between the customer personality and the bank will cause that customer has commitment feeling to the bank. Commitment feeling can help to more intimacy of customer and banks. In conjunction with these components can also be said, customer commitment to business strengthens the word of mouth advertising, it means that when commitment is created in customer towards the bank, will cause customer does positive advertising for bank to others and encourage them to use the bank financial services. In elaborating and interpreting the relationship between personality congruency and partners' quality can be said that to perceiving bank customers with necessary competencies against rivals, creating a perfect fit between the customer personality and the bank is a necessity. On the other hand, the partners' quality or merit of business strengthens the word of mouth advertising; when bran (banks) has the necessary competencies to other competitors, will cause that customer does positive advertising for bank to others and encourage them to use the bank financial services. This study in addition to the results mentioned, containing a series of recommendations that will help the banking sector managers to contact their customer in a better and more favorable manner and are seeking to attract their consent.

\section{Proposals and Limitations of the study}

The findings of this study include practical recommendations and suggestions for bank managers. New researches in the field of branding is explaining this issue in marketing that create balance and provide the needs and values of customers, ie create congruency between the values of business and customers can create lasting bonds between the customer and business. In total main recommendations resulting from this research include:

1. The results show that all aspects of the customer personality and the bank: Responsibility, affective, mobility, simplicity, and boldness in both groups (customer and bank) have fairly substantial importance in the view of customers. Therefore, it is recommended that bank managers should pay attention on the one hand, to the dimensions of the customer and the brand, and on the other hand, to creating a balance between them. There are two very important factor that strength and order personality dimensions it means that staff and the experience that customers have in direct contact with them and other is foreign source of information of bank that indirectly affect consumers' behavior. Thus, managers can adjust bank's staff and resources in line with the personality characteristics of their customers. 
2. Marketing in the new age is defined as creating, maintaining and enhancing strong relationships with customers. As far as the literature suggests that marketing is increasingly moving away from individual transactions and move toward building a relationship with customers. The findings and conclusions suggest that all aspects of the customer-bank relationship (intimacy, self-communication, effective commitment and partners' quality) is important in the view of customers. Hence, it is suggested to managers to strengthen this dimension, have a good plan. Business can claim that has created a good and strong relationship with the customer when provides the values and desires of its customers.

3. According to the results of the study and confirming the relationship between the variables in the model of research, the directors recommended to provide positive advertising to bank by creating a lasting relationship using creating and improving congruency with the customer and bank. Of course, one of the consequences of creating these advertising among customers will be attracting new customers to the bank.

4. Given the demographic characteristics can help to managers in planning in order to better achieving to business goals. The results and analysis show that in customer and the brand personality dimensions are only two dimensions that according to gender (men and women) are controversial and there isn't an exception for other demographic variables. Hence, it is suggested to bank managers that in planning and policy in the field of customer persona, "individual responsibility" and the brand personality, "the brand dynamic" pays more attention. Because it has more importance for women group.

In the process of doing any research and scientific projects, there are causes and factors that as obstacle and constraint cause slowing speed and research to achieve the goal. Therefore, there are some limitations that we face in research:

1. The population of the study: One of the main limitations of this study is the population. Because the population is only Shahid Beheshti University students due to cultural differences, social and Ecology of the University with other universities, and even cab refer to differences in cultural, social, and demographic of this geographic area and other geographic areas. The cultural and social difference between universities will be effective on the results of the study and will deliver limited results. The social and cultural differences can be explained from the national perspective. Therefore, the results of this research are limit and practical to Shahid Beheshti University.

2. The absence of similar studies for comparison: The second main limitation of the study is the lack of similar studies to compare the results with them. As described in the literature, there is no research about investigating the personality congruency and dimensions of variable of customer-bank relationship. Furthermore, there is no research about investigating relationship of dimensions of customer-bank relationship with word of mouth advertising. Therefore, the results of this study cannot be compared with other research. However, the literature shows that there are some researches that have investigated the relationship between personality variables, personality congruency, customer-business relationship and word of mouth advertising.

\section{References}

1. Hamidizadeh MR, Karimi Aluijeh MR, Rezaei, M. (2012). Investigating relationships of personality dimensions and brand equity and moderating role of moral traits, 2 (3): 3550.Dehdashti Shahrokh, Zohre, Taghavi Fard and Rostami, N. (2010). "A model for 
measuring the impact of brand trust of banks on customers' loyalty commitment". Journal of Management Sciences in Iran, Issue 20, Winter 2010, 69-88.

2. Dehdashti Shahrokh, Zohre, Jafarzade Kenari, Mehdi, and Bakhshizadeh, AR (2012). Investigating view of brand social identity and its influence on brand loyalty development (Case study: The manufacture company of Kale products). Journal of new marketing, second year, the second number, serial number (5), 106-87.Rezaei, Hossein, and Mohammad Shafie, Majid. (2009). Investigating the ages of marketing with a new approach to the ethics of marketing. Commerce survey, Issue 34, 19-27.

3. Rezaei, M. (2012). Investigating the impact of moral traits on personality dimensions and creating brand equity (Master thesis). Shahid Beheshti University, Faculty of Management and Accounting.Ranjbarian, B, Barari, Mojtaba. (2009). Marketing of customer relationship, An approach to improve customer satisfaction. Journal of executive management, the ninth year, the second issue, (36), 63-82.

4. Seyed Javadiyan, SR, Barari, M, and Allahyari, A. (2011). Explain the relationship of behavioral positive consequences of staff with customers of selected banks. New marketing research, first year, the third number, 129-144.Azizi, Sh, Ghanbarzadeh Miyandehi, R., and Fakharmanesh, S. (2012). Assess the impact of brand personality on attitudinal and behavioral loyalty of customers: case study of Hayper Star brand. Volume 16, Issue 4, Pages 105-124.Hawkins, Del. Bast, Rajer.kany, Kenneth (2006). Consumer behavior (Translator: doctor Ahmad Rusta, Arye Barhorayi ) Tehran, Sargol.

5. Aaker, D.A. (1996), Building Strong Brands, The Free Press, New York, NY, pp. 35, 71.

6. Aaker, J. (1997). Dimensions of Brand Personality. Journal of Marketing Research, 34, 347-356.

7. Aaker, Jennifer, Susan Fournier, and S. Adam Brasel (2004), "When Good Brands do Bad", Journal of Consumer Research, 31, 1-16.

8. Ardndt, J. (1967). Role of Product Related Conversations in Diffusion of a New Product. Journal of marketing research, 4(3), 291-295.

9. Ardndt, J. (1967). Role of Product Related Conversations in Diffusion of a New Product. Journal of marketing research, 4(3), 291-295.

10. Azoulay, A., and Kapferer, J. N. (2003). Do Brand Personality Scales Really Measure Brand Personality?. Journal of Brand Management, 11(2), 143-155.

11. Belk, R.W. (1988). Possessions and the Extended Self. Journal of Consumer Research, 15, 139-68.

12. Crosby, L., Evans, K., and Cowles, D (1990). Relationship Quality in Service Selling: An Interpersonal Influence Perspective. Journal of Marketing, 54 (3): 68-81.

13. Dolich, I.J. (1969. Congruence Relationships between Self Images and Product Brands. Journal of Marketing Research, 6, 80-4.

14. Freling, T. H. and Forbes, L. P. (2005). An empirical analysis of the brand personality effect. Journal of Product and Brand Management. 14(7), 404413.

15. Geuens, M., Weijters, B., and K. D. Wulf. (2009). A New Measure of Brand Personality. Intern. J. of Research in Marketing, 26, 97-107.

16. Gremler, D. D., Gwinner, K.P., and Brown, S.W. (2001). Generating Positive Word ofMouth through Customer-Employee Relationships. International Journal of Service Industry Management, 12(1), 44-69.

17. Gutman, J. (1982). A Means-End Chain Model Based on Consumer Categorization Processes, Journal of Research 46, 60-72. 
18. Hamm, B.C., and Cundiff, E.W. (1969). Self-Actualization and Product Perception”, Journal of Marketing Research, 6, 470-482.

19. Hennig-Thurau, T., Gwinner, K. P., and Gremler, D. (2002). Understanding Relationship Marketing Outcomes: An Integration of Relational Benefits and Relationship Quality. Journal of Service Research, 4, 230-47.

20. Hosany, S., and Martin, D. (2011). Self-Image Congruence in Consumer Behavior. Journal of Business Research, Under print.

21. John O. P., Srivastava S. (1999). “The Big Five Trait Taxonomy: History, Measurement and Theoretical Perspectives”. In L. A. Pervin, \& O. P. John (Eds.), Handbook of personality. New York: The Guilford Press.

22. Kapferer J-N. (2008). The New Strategic Brand Management, Creating and Sustaining Brand Equity Long Term. London: Kogan Page.

23. Kotler, P. (1997). Marketing Management: Analysis, Planning, Implementation and Control. New Jersey: Prentice-Hall, Inc.

24. Lee, H., and Kang, M. S. (2010). The Impact Of Brand Transgressions On Relationship Strength: Moderating Roles Of Brand Personality And Consumer Loss Type. Proceedings of the Academy of Marketing Studies, 15(1), 29-35.

25. Lin, L.Y. (2010). The Relationship of Consumer Personality Trait, Brand Personality and Brand Loyalty: An Empirical Study of Toys and Video Games Buyers. Journal of Product \& Brand Management, 19(1), 4-17.

26. Litvin, S. W and Goldsmith, R. E Pan, B. (2007). Electronic Word-Of-Mouth in Hospitality and Tourism Management. Tourism Management, 29(3), 458-468.

27. Maehle, N., Shneor, R. (2010). On Congruence Between Brand and Human Personalities. Journal of Product \& Brand Management, 19(1), 44-53.

28. Martineau, P. (1957). Motivation in Advertising, McGraw- Hill, New York, NY.

29. Maxham, J., and Netemeyer, R. (2002). A Longitudinal Study of Complaining Customers' Evaluations of Multiple Service Failures and Recovery Efforts. Journal of Marketing, 66 (4): 57-71.

30. Morgan, R., and Hunt, S. (1994). The Commitment-Trust Theory of Relationship Marketing. Journal of Marketing, 58 (July): 20-38.

31. Mowen J. C. E., and Minor M. (1998). Consumer Behaviour - 5th edition. Prentice Hall.

32. Ng, S. Meredith., David, M, E., and Dagger. T. S. (2011). Generating Positive Word-Of Mouth in the Service Experience. Managing Service Quality, 21(2), 133-151.

33. Nobre, H. M., Becker, k., and Brito, C. (2010). Brand Relationships: A PersonalityBased Approach. J. Service Science \& Management, 3, 206-217.

34. Park, S.Y., and Lee, E.M. (2005). Congruence between Brand Personality and SelfImage, and the Mediating Roles of Satisfaction and Consumer-Brand Relationship on Brand Loyalty. Asia-Pacific Advances in Consumer Research, 6, 39-45.

35. Park, S.Y., and Lee, E.M. (2005). Congruence between Brand Personality and SelfImage, and the Mediating Roles of Satisfaction and Consumer-Brand Relationship on Brand Loyalty. Asia-Pacific Advances in Consumer Research, 6, 39-45.

36. Plummer, J.T. (2000). How Personality Makes a Difference. Journal of Advertising Research, November-December, 79-82.

37. Pruitt, D. (1981). Negotiation Behavior. New York, Academic Press, Inc. 
Bulletin de la Société Royale des Sciences de Liège, Vol. 85, 2016, p. 1514 - 1528

38. Shan, X. (2012). On Congruence between Human and Brand Personalities in Chinese Culture Context (master's thesis). Retrieved from http://brage.bibsys.no/hia/retrieve/ 6016/Oppgave \%20 Shan\%20 Xiao.pdf 